DOI https://doi.org/10.30525/978-9934-26-004-9-55

\title{
ПРОБЛЕМА ЗМІСТІВ Й ФОРМОТВОРЕННЯ ТЕАТРАЛЬНОГО ВБРАННЯ ДЛЯ П'ЄС ОСКАРА ВАЙЛДА: НА ПРИКЛАДІ КОМЕДІЇ «ЯК ВАЖЛИВО БУТИ СЕРЙОЗНИМ»
}

\author{
Несен I. I. \\ кандидат історичних наук, доиент, докторант, \\ дочент кафедри мистечтвознавчої експертизи \\ Національної академії керівних кадрів культури і мистецтва \\ м. Київ, Украӥна
}

Драматургія Оскара Вайлда активно студіюється багатьма дослідниками. Його трагедії й комедії одночасно сповнені естецького символізму, містерії й літературної критики. Однак, вивчаються вони переважно за особливостями тексту філологами $[2 ; 3 ; 4 ; 5] .3$ погляду ж мистецької стилістики театрального втілення, коло публікацій вкрай обмежене.

У цій статті ми зосередимось на аналізі театрального вбрання як проблемі формотворення й змістів вистави, яка втілює погляди Вайлда на шляхи розвитку британського костюму у період згасання вікторіанських традицій. У такий спосіб відкриваються можливості новітніх трансформацій у театральній практиці, авторських концепцій щодо вбрання, втілених у поняттях екстравагантність й дендизм [1]. Для досягнення цієї мети, ми обрали комедію «Як важливо бути серйозним», поставлену на лондонській сцені у 1895 р. й означену в афіші за жанром, як легковажну комедію для серйозних людей.

Текст комедії не містить авторських ремарок про вбрання героїв. У класичній театральній сценографії межі XIX-XX ст. до цього твору вживався переважно костюм модерну. Отже, вистави за творами О. Вайлда, які відбувались за його життя, були побудовані на класичній сценографії й використанні костюмів своєї епохи. Натомість головні герої комедії Алджернон Монкріф й Джон Уорнінг належать до парадоксального вайлдівського архетипу естетів-денді. Їх вбрання втілює авторську філософію нереального. Для творення цього образу-архетипу костюм - один із найважливіших маркерів естетства персонажу, моделювання образу. Через тривалу заборону показу вистав О. Вайлда, розвиток сценографічних моделей й театрального вбрання перервались як в Англії, так і за іiі межами. В Англії вистава «Як важливо бути 
серйозним», через скандальне ув'язнення автора, була на довго заборонена і в театральній практиці Британії відновилась лише у 1946 р.

В Україні вистави за творами О. Валда з'явились лише в часи Незалежності. Спочатку «Як важливо бути серйозним» було поставлено на сцені Театру російської драми ім. Л. Українки, що у Києві. В останнє десятиліття з'явились нові постановки львівського театру ім. Заньковецької «Віяло леді Віндермір» та «дееальний чоловік» (режисер Федір Стригун, художниця Людмила Боярська).

Новітня постмодерна версія комедії під назвою «Серйозно» була представлена глядачам восени 2020 р. київським театром «Veritas» (режисерка Олександра Кравченко, художниця-постановниця Тетяна Бєлік). У ній театральний костюм зіграв особливу роль у розгортанні фабули сюжету. Філософія естетизму О. Вайлда чудово вписалась у концепцію філософсько-інтелектуальної вистави яку обстоює трупа «Veritas».

На початку дії перед глядачами постають освітлені концентрованим променем дві групи акторів (іх семеро - I.H.) у чорних трико, босоніж, які здаються готовими до пантоміми. Цю монохромну колірність порушує чоловік у бузковому костюмі, що уособлює собою самого автора. Він виносить на сцену закутану у білий згорток валізу, з якої поволі роздає кожному учаснику елементи їх вбрання і взуття. Вони вбирають його тут же на сцені і перетворюються у конкретних персонажів - Алджернона Монкріфа й Джона Уорнінга, його молоду вихованку Сесілі Кардью і гувернантку міс Призм, а також каноника Чезюбла, леді Брекнел і $і 1$ доньку Гвендолен Ферфакс.

Весь одяг, що його роздав автор, за конструкціями вкрай простий. У жінок це розпашні спідниці з оборкою, до яких додано аксесуари. Кожен 3 комплектів відмінний за кольором: у міс Призм лимонно-жовтий стрій. Ïї господарську функцію маркує фартух, вбраний поверху спідниці. Два дівочі комплекти трав'янисто-зеленого і рожевого кольорів. Спідниця леді Брекнел ніжного персикового тону 3 оборкою кольору кава 3 молоком. Ї̈̈ родинний статус позначений повною довжиною спідниці і брижовим коміром. До спідниць додаються шалі або шарфики невимушено пов'язані на шиях.

Чоловіче вбрання, семантично пов'язане з дендизмом і вирішене лише деталлю - грудною манишкою, яка пов'язана навколо торсу i доповнена бузковими шарфами на шиях. Ця найважливіша деталь, за задумом художниці, зображує цілий костюм. У другій частині вистави виникає ще один улюблений вайлдівський аксесуар чоловічого 
костюма - бутоньєрки. У момент конфлікту між молодиками, вони знак примирення.

Зазначимо, що вистава майже позбавлена декорацій. Лише стільці під стінами, на яких від початку вистави сидять актори; підставка, яку біла обгортка 3 валізи перетворює на столик. На ньому білі квіти у горщику. Місце столика час від часу змінюється, залежно від характеру мізансцен. Останній атрибут, який весь час на сцені - валіза як символ сюжету і змісту.

Для прояснення описаної стилістики театрального вбрання варто звернутися до поглядів Вайлда на дизайн костюму, які мистець сповідував у 1880-і pp. і втілив їх у своїх статтях і лекціях. У його концепціях раціональність і дендизм несподівано переплелися. Згадаємо, як у своїй відомій американській мандрівці 1882 р. й у подальшому, він обстоював необхідність носити виключно зручний одяг вільного спадаючого покрою й його колірну вишуканість. У пошуках нових конструктивних підходів він підтримав ідею «роздвоєної» жіночої спідниці. У силуеті він цінував складки й оборки, оскільки саме ці елементи крою підкреслювали поставу у русі. У підборі кольорів письменник шукав і пропонував глибокі або ніжні природні відтінки. Звідси його «ніжно-жовтий колір примули» або «темно-зелений колір яблуневого листя».

Інноваційні концепції Вайлда виводили його у театральний простір і приковували увагу до сценічного костюму. Пишучи свою комедію «Як важливо бути серйозним» він надихався сценічними образами i костюмами відомого англійського актора Чарльза Уїндема $(1837-1919$ pp.)

Нам здається, що художниця Т. Бєлік, застосувавши у творенні типу костюму для комедії «Серйозно» метод колажу, інтерпретувала як раціональність, так й естетизм Вайлда. Коли дивишся на ії дендіманишки, згадуєш дуже близькі до такого прочитання стилістики костюму думки письменника: «Цвет сюртука будет символическим, что явится частью замечательного символического движения в искусстве. Воображение сосредоточится на жилетах. По жилету можно будет судить, способен ли человек восхищаться поэзией. Это будет очень ценно. Перед рубашки расскажет, наделен ли он фантазией. С первого взгляда можно будет опознать зануду» [1, с. 462]. Завдяки обраному силуету i принципу конструювання жіночого вбрання, яке нагадує розпашні спідниці, створено можливість активного введення в малюнок акторської гри елементів пантоміми.

Костюми Т. Бєлік, створюють нерозривну єдність змісту і форми: бесіди у формі іронічних каламбурів, Сесілі Кардью, яка весь час має 
вчитися, зображає цей нюанс, сидячи біля стосу, перев'язаних стрічкою $з$ бантом книжок величезних розмірів. Щоб закріпити всі знання, вона веде щоденник великого формату у хутряній обкладинці. За правилами дендизму, актори вивчають одне одного крізь лорнет, що його демонстративно тримає між ними актор-Вайлд.

По мірі наближення сюжету до розв'язки, персонажі скидають з себе вайлдівські вбрання. Засобами пантоміми вони знімають 3 себе i згортають костюми, які знову потрапляють до валізи. Останньою роздягається леді Брекнел. Вайлд так і залишається у своєму бузковому костюмі. В останній мізансцені актори гойдають його на руках.

Висновки. «Дендизм» у п’єсі Вайлда «Як важливо бути серйозним» наділений винятково рисами чеснот і привабливості, без жодного негативу. Авторські концепції у галузі дизайну костюму до сьогодні актуальні для створення постпостмодерного сценічного вбрання. У цьому переконує вистава київського театру «Veritas» «Серйозно», де костюм має рольову функцію у розгортанні сюжету, метафоричність й образність мислення. Костюм й обрані предмети тут єдиний зоровий чинник вистави, іiі образотворча партитура.

Увага до розширеної функції костюму у театральній виставі підкреслює конфлікт до декорацій. Дія відбувається у нейтральній оздоблювальній фактурі - чорне драпірування навколо простору сцени засвідчує індиферентне ставлення авторів до відтворення інтер'єру часів англійського модерну. Саме костюм $є$ відтворенням змісту комедії й мистецької ідеології життя іiї автора. Бузковий колір упродовж усієї дії сприймається як символ епохи. Особливе місце у виставі має освітлення. Серед його засобів пожднані концентрований промінь і затемнення сцени.

\section{Література:}

1. Вайнштейн О. Денди. Мода. Литература. Стиль жизни. М.: Новое литературное обозрение, 2005. 640 с., ил.

2. Валова О.М. «Философия дендизма» в комедиях Оскара Уайльда. Вестник Вятского государственного гуманитарного университета. Серия: Филология и искусствоведение. Киров, 2012. № 2/2. С. 161-165.

3. Валова О.М. «Искусству случай мил, искусство - случаю» (к вопросу о роли случайности в комедиях Оскара Уайльда). Известия Волгоградского государственного педагогического университета. Серия: Филологические науки. 2014. № 7 (92). С. 113-118.

4. Янченко Ю. В. Естетизм О. Уайльда в оцінках сучасних літературознавців. Література в контексті культури. 2011. Вип. 21(2). C. 297-305. URL: http://nbuv.gov.ua/UJRN/lvk_2011_21\%282\%29_52. (Дата звернення 10 листопада 2020 р.). 
5. Янченко, Ю. В. Художньо-естетична своєрідність казок Оскара Уайльда. Наукові записки Харківського національного педагогічного університету ім. Г.С. Сковороди. Серія: Літературознавство. 2009. Вип. 3 (1). С. 74-80. URL: http://nbuv.gov.ua/UJRN/Nzl_2009_3\%281\% 29 _10. (Дата звернення 10 листопада 2020 р.).

DOI https://doi.org/10.30525/978-9934-26-004-9-56

\title{
СИМВОЛІЧНИЙ жИВОПИС МИХАЙЛА САПОЖНИКОВА (1871 - 1937). СЬОГОДЕННІ ПРАКТИКИ ДОСЛІДЖЕННЯ ТА ПРЕЗЕНТАЦЇ̈
}

\author{
Несмачний С. М. \\ аспірант \\ Національної академії керівних кадрів культури і мистецтв \\ м. Київ, Украӥна, \\ заступник директора з наукової роботи \\ Комунального закладу культури «Дніпропетровський художній музей» \\ Дніпропетровської обласної ради» \\ м. Дніпро, Україна
}

Перша чверть XX століття - динамічна, складна та драматична фаза розвитку вітчизняної культури і образотворчого мистецтва зокрема.

На початку XX століття в Україні надзвичайно активізувалось культурне життя - це час небаченого злету інтелектуальної думки, виникнення і поступу розмаїття естетичних та філософських концепцій, бурхливого розвитку нових мистецьких напрямів й художніх практик та появи плеяди яскравих творчих індивідуальностей $[0,86]$.

Співіснування різноспрямованих течій в образотворчому мистецтві характерна ознака того часу. Тоді ще активно діють пересувні художні виставки, учасники яких відстоюють принципи демократичного реалізму, і в цей же час ряд українських художників освоюють сучасні на той момент європейські мистецькі напрями - від імпресіоністичного творчого методу до найактуальніших модерних та авангардних художніх практик.

Однією 3 ключових літературно-мистецьких складових тогочасної культури був символізм. Саме 3 ідеями та естетикою символізму в образотворчому мистецтві пов'язана визначальна частина творчого доробку Михайла Сапожникова (1871 - 1937), який жив та працював в Катеринославі-Дніпропетровську в першій третині XX століття. 